\title{
Argemone Oil and Butter Yellow Induced Toxicity in Hepatic and Extra Hepatic Tissues
}

\author{
Vivek Mishra $^{1,2 *}$, Manjari Mishra ${ }^{1}$, Bhushan P Chaudhari ${ }^{1}$, Raj Khanna ${ }^{2}$ and Mukul Das ${ }^{1}$
}

${ }^{1}$ CSIR-Indian Institute of Toxicology Research, Council of Scientific and Industrial Research, Lucknow, India ${ }^{2}$ Department of Biochemistry, University of Lucknow, Lucknow, India

\begin{abstract}
Objective: The present study was designed to evaluate the toxicological potential of argemone oil $(\mathrm{AO})$ and butter yellow (BY).

Methods: Short term treatment through intraperitoneal administration in hepatic tissue and long term treatment through diet in hepatic and extra hepatic tissues was performed in mice.

Results: Short term study showed that female mice were more prone towards risk associated with liver damage than the males. Further investigations in female mice given $A O(1 \%)$ and $B Y(0.06 \%)$ through diet for 180 days, showed significant weight loss and increase in liver weight. Phase I and Phase II enzymes, antioxidant enzymes and glutathione content were significantly decreased with concomitant increase in lipid peroxidation (LPO) in AO and BY treated mice. Animal fed with $A O$ and $B Y$ showed profuse hyperplasia along with fluid filled spaces and patches of hemorrhage in hepatic tissue. AO treated animals showed tumorigenic growth, while BY treatment caused multiple nodule formation in hepatic tissue. Other organs like heart, lungs, kidney and spleen also showed substantial histopathological changes.

Conclusion: The results suggest that AO and BY treatment may cause oxidative stress and inhibited phase I and II enzymes leading to accumulation of parent compound(s) or their metabolites, which may result in the tumorigenic/toxic responses in hepatic and extra hepatic tissues.
\end{abstract}

Keywords: Liver; Argemone oil; Butter yellow; Cancer; Female mice

\section{Introduction}

Edible oils and fats are the only source of essential fatty acids, add special flavors to food and maintain cell membrane integrity [1]. Among these oils, mustard oil from Brassica nigra seeds is the predominant cooking medium used in northeast India especially, the Gangetic basin [2]. Mustard oil is also used conventionally for skin and hair massage in this region. A variety of adulterants viz-a-viz argemone oil (AO), butter yellow (BY), thiocyanates etc., are added to mustard oil mainly for economic gains because of price variation between the pure and adulterated oil. Also huge gaps between supply and demand of edible oils and shortage of particular oil also prompt the unscrupulous traders to indulge in malpractice of adulteration.

Consumption of argemone contaminated mustard oil even for a short duration leads to a clinical condition collectively referred to as Epidemic Dropsy [3-5]. The toxic effects of AO have been attributed to the presence of benzophenanthridine alkaloids, sanguinarine and dihydrosanguinarine [6]. AO causes dilatation of the smaller arterioles and capillaries, leading to the leakage of serum albumin with a concomitant increase in globulin resulting in increased capillary permeability $[7,8]$. Experimental and clinical studies suggest that skin, liver, lungs, kidneys and heart are the target sites due to argemone oil toxicity [9-11].

4-Dimethyl-aminoazobenzene (Butter Yellow, BY) is a synthetic fat soluble, azo-dye used for commercial application in ink and paint industries. The degraded products of BY are considered to be carcinogens and teratogens [12]. Due to this fact, the EU and the US do not permit the use of this color as food-additives. However, in some countries this dye is occasionally used to enhance the color of bell pepper and chili powders [13]. Light pale cheaper oils, dyed with Butter yellow (BY) along with the addition of mustard pungency factor, allylisothiocyanate, are sometimes sold under the pretext of mustard oil [14]. In a set of over 100 mustard oil loose samples collected during
July 2002 from different markets of Lucknow, (India)showed that more than 50\% samples were artificially colored with BY [14]. Reports suggest that BY interacts with macromolecules like DNA and proteins to initiate toxic effects including genotoxicity and mutagenicity [13]. BY has been found to produce hepatic and skin tumors as well as cancer in the respiratory tract $[13,15,16]$.

Since AO and BY have been shown to be indiscriminately added to edible oils and both have genotoxic and carcinogenic/mutagenic potential $[13,17,18]$, the short term effect of these compounds following intraperitoneal (ip) administration was undertaken on Swiss albino mice (male and female, both) to evaluate the adverse effect on xenobiotic metabolizing enzymes and oxidative stress markers in the liver. Based on the short term study, long term administration of $\mathrm{AO}$ and BY in diet was further undertaken for 180 days, to evaluate the histopathological changes in hepatic and extra hepatic tissues of female mice.

\section{Materials and Methods}

\section{Chemicals}

7-Ethoxyresorufin (ERF), 7-pentoxyresorufin (PRF), nicotinamide

*Corresponding author: Vivek Mishra, CSIR- Indian Institute of Toxicology Research, Council of Scientific and Industrial Research, Post Box\#80, Lucknow-226 001, India, Tel: 091-7800343889; E-mail: vmishra27@gmail.com

Received December 06, 2013; Accepted January 01, 2014; Published February 10,2014

Citation: Mishra V, Mishra M, Chaudhari BP, Khanna R, Das M (2014) Argemone Oil and Butter Yellow Induced Toxicity in Hepatic and Extra Hepatic Tissues. Bioenergetics 3: 111. doi:10.4172/2167-7662.1000111

Copyright: $\odot 2014$ Mishra V, et al. This is an open-access article distributed unde the terms of the Creative Commons Attribution License, which permits unrestricted use, distribution, and reproduction in any medium, provided the original author and source are credited. 
adenine dinucleotide phosphate reduced (NADPH), bovine serum albumin (BSA) were purchased from Sigma Chemical Company, St. Louis, MO, USA. Argemone mexicana seeds were procured from outskirts of Lucknow city, UttarPradesh, India. The seeds were crushed and the oil was extracted with the help of Soxhlet apparatus using $\mathrm{n}$-hexane [19]. The hexane containing AO was filtered under vacuum through a Buchner funnel containing glass wool and the solvent was distilled at $30^{\circ} \mathrm{C}$ under vacuum in Buchii Rota vapor-R. The oil obtained was stored in amber glass bottle under nitrogen atmosphere. The yield of argemone oil from its seeds was 35\% (v/w) [17]. All other chemicals used were of highest purity commercially available.

\section{Animal treatment}

Short-term study: Healthy male and female Swiss albino mice (20 $\pm 3 \mathrm{~g}$ ), obtained from the animal breeding colony of Indian Institute of Toxicology Research (IITR, Lucknow, India), were acclimatized under standard laboratory conditions for 1 week prior to the experiment. Animals were housed in an air-conditioned room in plastic cages and maintained at $22 \pm 2{ }^{\circ} \mathrm{C}$ under standard laboratory conditions of light/ dark cycle (12-12 h) and had free access to food and water ad libitum. Mice were randomly divided into six groups of 10 each. Intraperitoneal (ip) injections of AO (5 ml/kgbwt) [17] and BY (25 mg/kg bwt) [20] were given twice weekly for 30 and 60 days. The animals of control group received $100 \mu \mathrm{l}$ injections (ip) of mustard oil twice weekly. During the treatment schedule, the animals were observed for daily food intake and body weight was recorded weekly. After 30 and 60 days of treatment, mice were sacrificed as mentioned in the guidelines for the care and use of laboratory animals of IITR. Liver was excised from the animals and weighed.

Long term study: Healthy female Swiss albino mice $(25 \pm 3 \mathrm{~g})$ obtained from the animal breeding colony of Indian Institute of Toxicology Research (Lucknow, India), were acclimatized under standard laboratory conditions for 1 week prior to the experiment. Animals were housed in an air-conditioned room in cages and maintained at $25 \pm 3^{\circ} \mathrm{C}$ under standard laboratory conditions of light/ dark cycle (12-12 h) and had free access to diet and water ad libitum. Mice were randomly divided into three groups (control, AO and BY). Two groups of mice were given either AO or BY mixed in diet daily for 180 days. The third group received the standard powder diet mixed with $1 \%$ mustard oil and served as controls. During the treatment schedule, the animals were observed daily and food intake was recorded. Body weight of animals was recorded weekly. Animals of all the groups were sacrificed by after 180 days as mentioned in the guidelines for the care and use of laboratory animals of IITR. Liver, lungs, kidneys and spleen were excised and weighed. Blood was collected in dry test tubes and allowed to clot at room temperature for $5 \mathrm{~min}$ followed by keeping it on an ice bath for $30 \mathrm{~min}$. Serum was separated from blood by centrifugation at $3000 \mathrm{x}$ g for $10 \mathrm{~min}$ and stored at $-80^{\circ} \mathrm{C}$ until further analysis.

\section{Preparation of diet}

Commercial pellet diet from Ashirwad, Chandigarh, India, was grinded and $\mathrm{AO}$ or $\mathrm{BY}$ were mixed to obtain $1 \%$ and $0.06 \%$ concentration, respectively. Fresh mixtures of diet containing AO and BY were prepared after every 15 days.

\section{Specimen collection and analysis of biochemical parameter}

A portion of liver was washed, weighed and homogenized in 10 volume $(\mathrm{v} / \mathrm{w})$ of chilled phosphate buffer $(0.1 \mathrm{M}, \mathrm{pH} 7.4)$ containing
$0.15 \mathrm{M} \mathrm{KCl}$, using a Potter-Elvehjem glass/Teflon homogenizer and centrifuged at $4^{\circ} \mathrm{C}$ at 9,000xg for 20 minutes to obtain S-9 fraction and stored at $-80^{\circ} \mathrm{C}$ for further analysis. This fraction was used for the assay of enzymatic antioxidants. Microsomal and cytosolic fractions were prepared by centrifugation of S- 9 fraction at 105,000 x gas described earlier [21] and stored at $-80^{\circ} \mathrm{C}$.

Lipid peroxidation and liver Sulfhydryl (Free -SH) content: Lipid peroxidation (LPO) in hepatic homogenate was measured as described earlier [22]. The extent of LPO was assayed by measuring the formation of malondialdehyde (MDA) and expressed as nmol MDA formed per hour per $\mathrm{ml}$ homogenate using a molar extinction coefficient of $1.56 \times 10^{5} \mathrm{M}^{-1} \mathrm{~cm}^{-1}$. The reduced glutathione (GSH) content was determined in hepatic homogenate as described by Ellman [23]. Briefly $10 \%$ homogenate $(1 \mathrm{ml})$ was mixed with $5 \%$ trichloro acetic acid (TCA) ( $1 \mathrm{ml})$, centrifuged at $825 \mathrm{xg}$ for $15 \mathrm{~min}$ and the supernatant $(0.5$ $\mathrm{ml}$ ) was mixed with 5-5'-dithiobis-2-nitrobenzoicacid(DTNB; $2.5 \mathrm{ml}$ ). The absorbance of the resulting mixture was recorded at $412 \mathrm{~nm}$. The GSH content was calculated in $\mu \mathrm{mol} / \mathrm{g}$ tissue.

Assay of antioxidant enzymes: Superoxide dismutase (SOD) activity in hepatic S-9 fraction was assessed based on its ability to inhibit the oxidation of epinephrine at alkaline $\mathrm{pH}$ [24] and expressed as nmol epinephrine oxidized/min/mg protein. Catalase (CAT) activity in S-9 was determined using $\mathrm{H}_{2} \mathrm{O}_{2}$ as substrate [25] and expressed as $\mu \mathrm{mol} \mathrm{H}_{2} \mathrm{O}_{2}$ consumed/min/mg protein.

Measurement of glutathione S-transferase (GST), quinine reductase (QR) activity: GST and QR activities were determined in hepatic cytosolic fraction according to standard protocols. The GST activity was determined by measuring the increase in absorbance of the reaction mixture [final volume of $3 \mathrm{ml}$ : phosphate buffer $(0.2 \mathrm{M}$; pH 6.5), GSH ( $9 \mathrm{mM}), 1$ - chloro-2, 4-dinitrobenzene (CDNB, 150 $\mathrm{mM})$ and cytosolic protein $(20 \mu \mathrm{g})]$ at $340 \mathrm{~nm}$ after every $30 \mathrm{sec}$ for $3 \mathrm{~min}$. The QR activity was determined by measuring the decrease in absorbance of reaction mixture [final volume of $3.0 \mathrm{ml}: 25 \mathrm{mM}$ Tris HC1 ( $\mathrm{pH} 7.4$ ), $0.7 \mathrm{mg}$ of bovine serum albumin, $0.01 \%$ Tween 20, $5 \mu \mathrm{M}$ flavin adenine dinucleotide FAD, $0.2 \mathrm{mM} \mathrm{NAD}(\mathrm{P}) \mathrm{H}, 10$ $\mu \mathrm{M}$ dicoumarol, $40 \mu \mathrm{M}$ dichlorophenol indophenols (DCPIP) as a substrate, and an appropriate amount of enzyme] at $600 \mathrm{~nm}$ after every $30 \mathrm{sec}$ for $3 \mathrm{~min}$. The activities of GST and QR were expressed as nmol conjugate formed $/ \mathrm{min} / \mathrm{mg}$ protein and pmol DCPIP disappeared/min/ $\mathrm{mg}$ protein, respectively.

Measurement of catalytic activities of CYP1A1 and CYP2B1: Catalytic activities of CYP1A1 (ethoxyresorufin-O-deethylase; EROD) and CYP2B1 (pentoxyresorufin O-dealkylase; PROD) were measured in hepatic microsomes essentially by the procedure of Pohl and Fouts [26] and Lubet et al. [27], respectively, with modifications as described by Das et al. [28]. The catalytic activities of CYP1A1 and CYP2B1 were calculated as $\mathrm{pmol}$ resorufin formed/min/mg protein.

Protein estimation: Protein in different fractions of liver was measured according to the method of Lowry et al. [29], using bovine serum albumin as standard.

\section{Western blot analysis of CYP1A1 and CYP2B1 protein}

Hepatic microsomes from each group (control, AO and BY) were electrophoresed through 10\% SDS-polyacrylamide gels. Separated proteins (CYP1A1, CYP2B1) were transferred onto polyvinylidene difluoride membranes. After blocking the membranes with $1 \%$ BSA in tris buffer saline with tween (TBS-T) $[20 \mathrm{mmol} / \mathrm{L}$ Tris, $150 \mathrm{mmol} / \mathrm{L}$ 
$\mathrm{NaCl}(\mathrm{pH} 7.5), 0.02 \%$ Tween 20] for $1 \mathrm{~h}$ at room temperature the membranes were then incubated with rabbit polyclonal primary antibodies of CYP1A1 and CYP2B1 (1:1000) followed by incubation with anti-rabbit secondary antibody conjugated to horse radish peroxidase system (1:2500), washed again using TBS-T and bands were detected by the enhanced chemiluminescence western blotting substrates (Thermo Fisher Scientific, Rockford, IL, USA) [30]. All experiments were repeated at least twice.

\section{Estimation of plasma protein fractions}

Total protein and albumin (A) content in serum was assayed by Accurex Biomedical kits (Mumbai, India). Globulins (G) and A/G ratio were calculated from these values and expressed as $\mathrm{g} / \mathrm{dl}$.

\section{Histopathological observation}

A portion of liver, heart, lungs, kidneys and spleen was fixed in 10\% buffered formalin and embedded in paraffin. Sections of $5 \mu \mathrm{m}$ thickness were cut and stained with hematoxylin and eosin for microscopic examination [31].

\section{Statistical analysis}

All results were expressed as the mean \pm standard error (SE), as indicated in the tables. Statistical analysis of variance was carried out using one way ANOVA [32]. A value of $p<0.05$ was used as the level of significance.

\section{Results}

Effect of intraperitoneal administration of AO and BY on body weight gain, relative liver weight and liver to body weight ratio

The change in body weight gain, liver weight and liver/bwt ratio in $\mathrm{AO}$ and $\mathrm{BY}$ treated male and female mice during the experimental schedule is given in Table 1. Significant reduction in body weight gain was observed in $\mathrm{AO}$ and BY treated female mice after 30 and 60 days of exposure, while no effect on body weight gain was observed in case of male mice. During 30 and 60 days of $\mathrm{AO}$ and $\mathrm{BY}$ exposure, female mice showed significant increase in liver weight and liver/bwt ratio while male had no effect.

\section{Effect of intraperitoneal administration of $\mathrm{AO}$ and $\mathrm{BY}$ on} oxidative stress marker and xenobiotic metabolizing enzymes

No significant increase in LPO was observed during 30 days of $\mathrm{AO}$ or BY treatment to male and female mice (Table 2). However, twice weekly parenteral administration of $\mathrm{AO}$ for 60 days resulted in 132 and $261 \%$ increase in LPO in male and female mice, respectively. Further, no change in LPO was observed in BY treated groups (male and female) during 60 days of exposure. Significant decrease $(31,30 \%$ and $32,32 \%$ ) in free -SH content was observed in AO treated male and female animals following 30 and 60 days of exposure. BY treatment to male and female mice for 30 and 60 days resulted in no significant change in free $-\mathrm{SH}$ content. Twice weekly administration of $\mathrm{AO}$ to male and female mice for 30 and 60 days caused significant decrease (25 and 36\%) in EROD activity. However, BY treatment caused no substantial change in EROD activity either in male or female animals. No significant change in GST activity was observed in male and female mice exposed to $\mathrm{AO}$ or BY for 30 days. However, exposure to BY in male and female animals for 60 days resulted in 37 and 32\% decrease in GST activity, respectively. Further, GST activity was found to be inhibited (50\%) in female mice treated with AO for 60 days. Significant decrease in QR activity was observed in all the treated groups (AO or $\mathrm{BY}$ ) of male and female mice after 30 and 60 days of exposure.

Effect of dietary exposure of AO and BY on body weight gain, relative liver weight and liver marker enzymes

The trend in body weight gain (percent increase), liver weight and liver/bwt ratio in control, $\mathrm{AO}$ and $\mathrm{BY}$ treated female mice during the experimental schedule is given in Table 3. During the180 days of exposure significant reduction in body weight gain was observed in $\mathrm{AO}$ and BY treated mice (Table 3). Average diet consumption was found to be comparable in $\mathrm{AO}$ or BY treated group and no different than that of controls. AO and BY treatment resulted in significant increase in liver weight (19and61\%).However, significant increase in liver weight and liver/bwt ratio was found in $\mathrm{BY}$ exposed group only, but not in the $\mathrm{AO}$ exposed group (Table 3 ).

\section{Effect of dietary exposure of $\mathrm{AO}$ and $\mathrm{BY}$ on oxidative stress and antioxidant enzymes}

Administration of $\mathrm{AO}$ and $\mathrm{BY}$ through diet resulted in significant increase in LPO to an extent of 288 and $76 \%$, respectively, when compared to control. Both $\mathrm{AO}$ and $\mathrm{BY}$ caused significant depletion of free -SH content when compared to control (Table 4). AO and BY exposure to mice for 180 days resulted in significant decrease $(\mathrm{p}<0.05)$ in SOD and catalase activity (Table 4).

Effect of dietary exposure of AO and BY on Phase I and Phase II enzymes activity and status of CYP1A1 and CYP2B1 protein

Activities of Phase I (EROD, PROD) enzymes and Phase II (GST, $\mathrm{QR}$ ) enzymes following $\mathrm{AO}$ and $\mathrm{BY}$ exposure is delineated in Table 4. Significant decrease $(\mathrm{p}<0.05)$ in EROD and PROD activity was observed in $\mathrm{AO}$ and $\mathrm{BY}$ treated groups after 180 days of exposure (Table 4). These findings were further substantiated with western blot analysis, which showed decreased level of CYP1A1 and CYP2B1 proteins following $\mathrm{AO}$ and $\mathrm{BY}$ exposure when compared to control (Figure 1). Phase II enzymes, GST and QR were also found to be decreased significantly in $\mathrm{AO}$ and $\mathrm{BY}$ exposed groups when compared to control (Table 4).

\section{Hepatic and extra hepatic changes following dietary exposure} to $A O$ and $B Y$

Dietary exposure of $\mathrm{AO}$ and $\mathrm{BY}$ resulted in hepatic tumors in female mice (Figure 2A). AO fed animals showed distinct tumors (four out of ten mice i.e. $40 \%$ ) in liver tissue, while multiple nodules (six out of ten mice i.e. $60 \%$ ) were observed in liver tissue of BY fed mice (Table 4). The average size of tumor in AO feed mice was $13.0 \mathrm{~mm}$ while size of multiple nodule were $1.46 \mathrm{~mm}$ (Table 4). Microscopic examination of control animals showed normal histology of liver, while liver of AO fed animals showed profuse hyperplasia of bile ductules, infiltration of inflammatory cells, vascular changes and fluid filled spaces along with hemorrhage patches (Figure 2B). Hepatic tissue of BY fed mice showed extensive hyperplasia of bile ductules as well as in liver parenchyma and many fluid filled spaces. Degenerative changes and infiltration of blood vessels were also observed (Figure 2B).

Dietary exposure to $\mathrm{AO}$ showed inflammation, degeneration and necrosis in heart, while BY treatment showed myocardial necrosis and infiltration of inflammatory cells (Figure 3A). Lungs of animals given $\mathrm{AO}$ and $\mathrm{BY}$ showed marked edema with cellular infiltration of 
Citation: Mishra V, Mishra M, Chaudhari BP, Khanna R, Das M (2014) Argemone Oil and Butter Yellow Induced Toxicity in Hepatic and Extra Hepatic Tissues. Bioenergetics 3: 111. doi:10.4172/2167-7662.1000111

Page 4 of 7

\begin{tabular}{|c|c|c|c|c|c|c|c|}
\hline \multirow[b]{2}{*}{ Parameter } & \multirow[b]{2}{*}{ Duration } & \multicolumn{3}{|c|}{ Male } & \multicolumn{3}{|c|}{ Female } \\
\hline & & Control & AO & BY & Control & AO & BY \\
\hline \multirow[b]{2}{*}{ Percent body wt gain } & 30 days & $51.7 \pm 1.5$ & $43.5 \pm 0.71$ & $43.8 \pm 2.21$ & $52.1 \pm 0.48$ & $\begin{array}{c}23.5 \pm 1.18 * \\
\quad(55 \%) \downarrow\end{array}$ & $\begin{array}{c}34.2 \pm 1.8^{*} \\
(34 \%) \downarrow\end{array}$ \\
\hline & 60 days & $78.6 \pm 0.41$ & $68.2 \pm 2.11$ & $72 \pm 1.78$ & $80.2 \pm 0.62$ & $\begin{array}{c}27.3 \pm 1.64 * \\
\quad(66 \%) \downarrow\end{array}$ & $\begin{array}{c}41.9 \pm 0.56 * \\
(48 \%) \downarrow\end{array}$ \\
\hline \multirow[b]{2}{*}{$\begin{array}{l}\text { Liver wt } \\
\text { (g) }\end{array}$} & 30 days & $1.63 \pm 0.08$ & $2.04 \pm 0.1$ & $1.91 \pm 0.24$ & $1.54 \pm 0.16$ & $\begin{array}{c}2.57 \pm 0.22^{*} \\
(67 \%) \uparrow\end{array}$ & $\begin{array}{c}2.63 \pm 0.28 * \\
(71 \%) \uparrow\end{array}$ \\
\hline & 60 days & $1.77 \pm 0.1$ & $1.89 \pm 0.12$ & $1.99 \pm 0.063$ & $1.62 \pm 0.05$ & $\begin{array}{c}2.5 \pm 0.13^{*} \\
(54 \%) \uparrow\end{array}$ & $\begin{array}{c}2.44 \pm 0.14^{*} \\
(51 \%) \uparrow\end{array}$ \\
\hline \multirow[b]{2}{*}{ Liver/bwt ratio } & 30 days & $0.07 \pm 0.001$ & $0.074 \pm 0.001$ & $0.073 \pm 0.002$ & $0.07 \pm 0.002$ & $\begin{array}{c}0.09 \pm 0.002^{*} \\
(29 \%) \uparrow\end{array}$ & $\begin{array}{c}0.09 \pm 0.003^{*} \\
(29 \%) \uparrow\end{array}$ \\
\hline & 60 days & $0.08 \pm 0.001$ & $0.075 \pm 0.001$ & $0.07 \pm 0.006$ & $0.065 \pm 0.001$ & $\begin{array}{c}0.081 \pm 0.001^{*} \\
(25 \%) \uparrow\end{array}$ & $\begin{array}{c}0.078 \pm 0.001^{*} \\
(20 \%) \uparrow\end{array}$ \\
\hline
\end{tabular}

Data represents mean \pm S.E. of five values. ${ }^{*} p<0.05$, Significant when compared to respective control

Values in parenthesis indicate percent change when compared to respective controls

Table 1: Effect of intraperitoneal administration of $A O$ and $B Y$ on body weight gain, relative liver weight and liver to body weight ratio.

\begin{tabular}{|c|c|c|c|c|c|c|c|}
\hline \multirow{2}{*}{ Parameter } & \multirow{2}{*}{ Duration (Days) } & \multicolumn{3}{|c|}{ Male } & \multicolumn{3}{|c|}{ Female } \\
\hline & & Control & AO & BY & Control & AO & BY \\
\hline \multirow[b]{2}{*}{ LPO (nmolMDA/ hr/gm tissue) } & 30 days & $4.32 \pm 1.29$ & $3.83 \pm 1.04$ & $4.39 \pm 0.11$ & $4.23 \pm 0.47$ & $6.93 \pm 1.24$ & $5.61 \pm 1.25$ \\
\hline & 60 days & $4.61 \pm 0.77$ & $\begin{array}{c}10.71 \pm 0.30 * \\
(132 \%) \uparrow\end{array}$ & $5.64 \pm 0.14$ & $4.70 \pm 2.69$ & $\begin{array}{c}17.01 \pm 3.16 * \\
(261 \%) \uparrow\end{array}$ & $6.06 \pm 0.64$ \\
\hline \multirow{2}{*}{ FreeSH ( $\mu \mathrm{mol} / \mathrm{gm}$ tissue) } & 30 days & $8.47 \pm 0.07$ & $\begin{array}{l}5.88 \pm 0.11^{*} \\
\quad(31 \%) \downarrow\end{array}$ & $8.47 \pm 0.28$ & $7.70 \pm 0.21$ & $\begin{array}{c}5.39 \pm 0.21^{*} \\
(30 \%) \downarrow\end{array}$ & $8.44 \pm 0.32$ \\
\hline & 60 days & $7.91 \pm 0.39$ & $\begin{array}{c}5.36 \pm 0.11^{*} \\
(32 \%) \downarrow\end{array}$ & $7.80 \pm 0.63$ & $7.60 \pm 0.32$ & $\begin{array}{c}5.18 \pm 0.21^{*} \\
(32 \%) \downarrow\end{array}$ & $8.23 \pm 0.70$ \\
\hline \multirow{2}{*}{ EROD (pmol/min/ mg protein) } & 30 & $333 \pm 22$ & $\begin{array}{c}249 \pm 66^{*} \\
(25 \%) \downarrow\end{array}$ & $298 \pm 5$ & $329 \pm 61$ & $\begin{array}{c}212 \pm 67^{*} \\
(36 \%) \downarrow\end{array}$ & $317 \pm 7$ \\
\hline & 60 & $268 \pm 11$ & $\begin{array}{c}190 \pm 36^{*} \\
(29 \%) \downarrow\end{array}$ & $278 \pm 15$ & $281 \pm 5$ & $\begin{array}{c}164 \pm 44^{*} \\
(42 \%) \downarrow\end{array}$ & $235 \pm 13$ \\
\hline \multirow[b]{2}{*}{ GST (nmol/min/mg protein) } & 30 & $2612 \pm 66$ & $2778 \pm 16$ & $2367 \pm 135$ & $2898 \pm 26$ & $2238 \pm 67$ & $2345 \pm 147$ \\
\hline & 60 & $2484 \pm 241$ & $1851 \pm 56$ & $\begin{array}{c}1560 \pm 80^{*} \\
(37 \%) \downarrow\end{array}$ & $2857 \pm 195$ & $\begin{array}{c}1429 \pm 218^{*} \\
(50 \%) \downarrow\end{array}$ & $\begin{array}{c}1935 \pm 104 * \\
(32 \%) \downarrow\end{array}$ \\
\hline \multirow{2}{*}{ QR (pmol/min/mg protein) } & 30 & $85 \pm 2$ & $\begin{array}{l}60 \pm 2^{*} \\
(29 \%) \downarrow\end{array}$ & $\begin{array}{l}30 \pm 1 * \\
(65 \%) \downarrow\end{array}$ & $90 \pm 1$ & $\begin{array}{l}70 \pm 1^{*} \\
(22 \%) \downarrow\end{array}$ & $\begin{array}{l}40 \pm 1 * \\
(56 \%) \downarrow\end{array}$ \\
\hline & 60 & $78 \pm 1$ & $\begin{array}{l}40 \pm 1 * \\
(49 \%) \downarrow\end{array}$ & $\begin{array}{l}30 \pm 1 * \\
(62 \%) \downarrow\end{array}$ & $82 \pm 1$ & $\begin{array}{l}40 \pm 1 * \\
(51 \%) \downarrow\end{array}$ & $\begin{array}{l}30 \pm 1 * \\
(63 \%) \downarrow\end{array}$ \\
\hline
\end{tabular}

Data represents mean \pm S.E. of five values. ${ }^{*} p<0.05$, Significant when compared to respective control Values in parenthesis indicate percent change when compared to respective controls

Table 2: Effect of intraperitoneal administration of $A O$ and $B Y$ on oxidative stress and xenobiotic metabolizing enzymes in mice.

\begin{tabular}{|c|c|c|c|}
\hline Parameter & Control & AO & BY \\
\hline Percent body wt gain & $7.8 \pm 0.32$ & $-3.07 \pm 0.41^{*} \downarrow$ & $-4.41 \pm .37^{*} \downarrow$ \\
\hline Liverweight (g) & $1.52 \pm 0.19$ & $1.81 \pm 0.11 *(19 \%) \uparrow$ & $2.45 \pm 0.37^{*}(61 \%) \uparrow$ \\
\hline Liver/bwt ratio & $0.053 \pm 0.005$ & $0.064 \pm 0.004$ & $0.078 \pm 0.009 *(47 \%) \uparrow$ \\
\hline Av. Dietconsumed (g/mice/day) & $3.84 \pm 0.11$ & $3.77 \pm 0.09$ & $3.29 \pm 0.24$ \\
\hline
\end{tabular}

Data represents mean \pm S.E. of six values. ${ }^{*} p<0.05$, Significant when compared to respective control

Values in parenthesis indicate percent change when compared to respective controls

Table 3: Effect of dietary exposure of $\mathrm{AO}$ and BY on bodyweight, food consumption, liver weight, liver/bwt ratio and live marker enzymes in mice.

inflammatory cells (Figure 3B). Kidney of AO and BY treated animals showed no prominent changes except that the presence of protein cast was observed within tubules (Figure 3C). Spleen showed profuse hyperplasia of bile ductules, lymphoid hypoplasia and prominent fibrous tissue septa in AO treated group, while BY treated animals also showed prominent fibrous tissue and lymphoid hypoplasia along with few megakaryocytes.

\section{Discussion}

The present study demonstrates the effect of short term (ip administration in male and female mice) as well as long term (through diet) exposure of $\mathrm{AO}$ and $\mathrm{BY}$ in female mice. The short term study indicates that females are more susceptible to AO and BY toxicity as compared to males. Taking the clue of female susceptibility from the short term study, chronic administration of AO and BY through diet for 180 days was performed, which resulted in toxicity not only in hepatic tissue but also in extra hepatic tissues. In short term study, a reduction in body weight gain (weight loss) in female mice in each of the treated group was noticed and similar findings were observed in long term treatment of $\mathrm{AO}$ and $\mathrm{BY}$ to female mice, although the diet consumption was not reduced significantly, which supports the symptoms of cachexia (unintended weight loss) [33]. Increased liver weight and liver to body weight ratio observed in female mice given $\mathrm{AO}$ and $\mathrm{BY}$ in short term and long term study indicates enhanced cell proliferation in liver. One of the characteristic feature of liver tumor promoter is increase in the liver size [34-36]. Virtually all xenobiotics 
Citation: Mishra V, Mishra M, Chaudhari BP, Khanna R, Das M (2014) Argemone Oil and Butter Yellow Induced Toxicity in Hepatic and Extra Hepatic Tissues. Bioenergetics 3: 111. doi:10.4172/2167-7662.1000111

\begin{tabular}{|c|c|c|c|}
\hline Parameter & Control & AO & BY \\
\hline $\begin{array}{l}\text { LPO (nmolMDA/hr/gm } \\
\text { tissue) }\end{array}$ & $4.46 \pm 0.26$ & $\begin{array}{l}17.32 \pm 1.12^{*} \\
(288 \%) \uparrow\end{array}$ & $\begin{array}{l}7.84 \pm 0.38^{*} \\
(76 \%) \uparrow\end{array}$ \\
\hline FreeSH ( $\mu \mathrm{mol} / \mathrm{gm}$ tissue) & $7.91 \pm 0.57$ & $\begin{array}{l}6.85 \pm 0.91^{*} \\
(13 \%) \downarrow\end{array}$ & $\begin{array}{l}4.26 \pm 0.34^{*} \\
(46 \%) \downarrow\end{array}$ \\
\hline SOD (nmol/min/mg protein) & $9.01 \pm 0.91$ & $\begin{array}{l}5.75 \pm 0.69 * \\
(36 \%) \downarrow\end{array}$ & $\begin{array}{l}5.27 \pm 0.57^{*} \\
(42 \%) \downarrow\end{array}$ \\
\hline $\begin{array}{l}\text { Catalase } \\
(\mu \mathrm{mol} / \mathrm{min} / \mathrm{mg} \text { protein })\end{array}$ & $10.28 \pm 0.80$ & $\begin{array}{l}8.42 \pm 0.57^{*} \\
(18 \%) \downarrow\end{array}$ & $\begin{array}{l}3.91 \pm 0.50 * \\
(62 \%) \downarrow\end{array}$ \\
\hline $\begin{array}{l}\text { EROD } \\
\text { (pmol/min/mg protein) }\end{array}$ & $299 \pm 13$ & $\begin{array}{l}222 \pm 23^{*} \\
(26 \%) \downarrow\end{array}$ & $\begin{array}{l}154 \pm 10^{*} \\
(49 \%) \downarrow\end{array}$ \\
\hline $\begin{array}{l}\text { PROD }(\mathrm{pmol} / \mathrm{min} / \mathrm{mg} \\
\text { protein) }\end{array}$ & $635 \pm 59$ & $\begin{array}{l}370 \pm 79 * \\
(42 \%) \downarrow\end{array}$ & $\begin{array}{l}145 \pm 13^{*} \\
(77 \%) \downarrow\end{array}$ \\
\hline $\begin{array}{l}\text { GST } \\
\text { (nmol/min/mg protein) }\end{array}$ & $2689 \pm 103$ & $\begin{array}{l}1351 \pm 245^{*} \\
(50 \%) \downarrow\end{array}$ & $\begin{array}{l}1297 \pm 66^{*} \\
(52 \%) \downarrow\end{array}$ \\
\hline QR (pmol/min/mg protein) & $126 \pm 15$ & $\begin{array}{l}80 \pm 6 * \\
(36 \%) \downarrow\end{array}$ & $\begin{array}{l}15 \pm 2 * \\
(88 \%) \downarrow\end{array}$ \\
\hline Number of mice with Tumor & $0 / 10$ & $4 / 10^{*}$ & $6 / 10^{*}$ \\
\hline Tumor size (mm) & Nil & $13 \pm 0.99$ & $1.47 \pm 0.18$ \\
\hline
\end{tabular}

Data represents mean \pm S.E. of six values. ${ }^{*} p<0.05$, Significant when compared to respective control

Values in parenthesis indicate percent change when compared to respective controls

Table 4: Effect of dietary exposure of $A O$ and $B Y$ on oxidative stress markers, antioxidant enzymes, xenobiotic metabolizing enzymes, number of mice with tumor and tumor size in female mice.

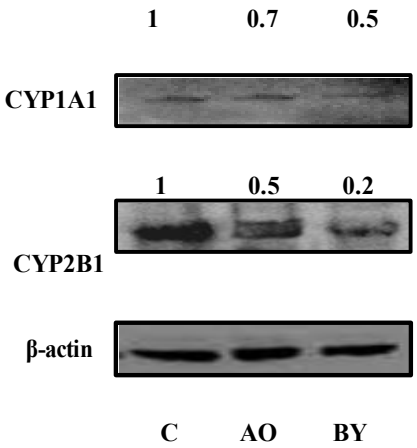

Figure 1: Effect of dietary exposure of $A O(1 \%)$ and $B Y(0.06 \%)$ on the levels of cyp1A1 and cyp2B1 proteins in liver of female mice. For Western blot analysis, liver cell lysates were prepared from five liver tissue of each group.

displaying liver tumor-promoting ability have been shown to induce hepatocellular proliferation. The compounds causing liver tumorpromoting activity (phenobarbital) were found to cause increases in liver-to-body weight ratios [37] which further supports our findings.

Phase I and Phase II enzymes play a critical role in hepatic injury. Impairment in phase I and phase II enzymes may be correlated with the decrease in metabolism of xenobiotics or slow elimination of xenobiotics from the body [9]. The decrease in phase I and phase II enzymes in AO and BY treated groups suggest that there may be slow elimination of parent compounds. The retention of the metabolite of $\mathrm{AO}$ and $\mathrm{BY}$ may reflect their toxic manifestation. Earlier studies have shown that phase I and phase II enzymes are inhibited in tumorigenic tissues [38]. The present study further demonstrates that the inhibition of hepatic phase I and II enzymes in mice fed with AO and BY may be due to tumorigenic response in hepatic tissue. This has been substantiated by the present study where long term exposure of female mice with $\mathrm{AO}$ and $\mathrm{BY}$ revealed hyperplasia, angiogenesis and infiltration of blood vessels in hepatic tissue. Although both AO
(40\%) and BY (60\%) caused tumor formation in liver, however the difference in the morphology of hepatic cellular structure indicates the differential response of these toxicants. Other organs like heart, lungs, kidneys and spleen also showed substantial histopathological changes following dietary administration of $\mathrm{AO} \& \mathrm{BY}$. The damage of hepatic and extra hepatic tissues in $\mathrm{AO}$ and $\mathrm{BY}$ fed mice may results in enhanced serum enzymes including alkaline phosphatase (ALP) and lactate dehydrogenase (LDH) [39].

Free radicals including reactive oxygen species (ROS) are continuously generated in the body by the biochemical redox reactions that occur as a part of normal cell metabolic process [40]. These unstable free radical species attack cellular components resulting in damage to

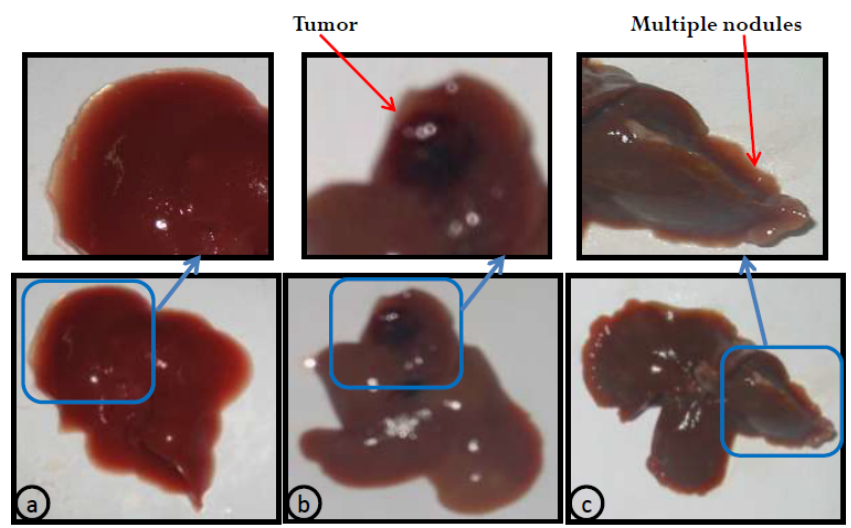

Control

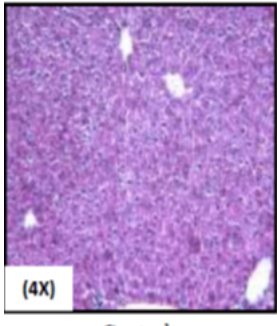

Control
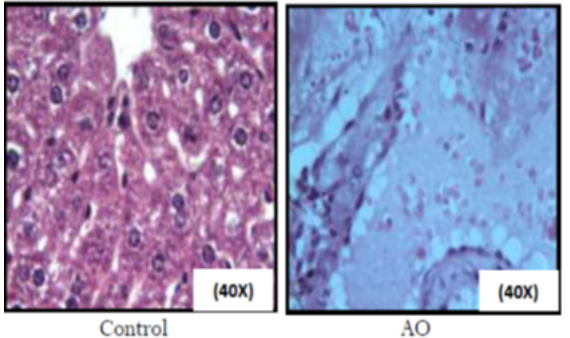

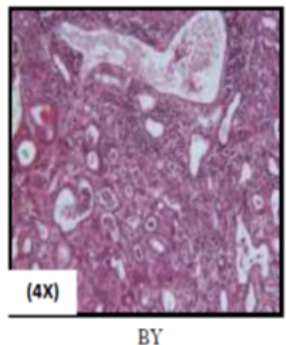

BY

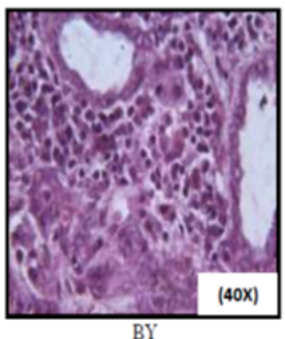

Figure 2: Effect of dietary exposure of $A O$ and $B Y$ on tumor formation and histopathology of liver. A: Liver of mice fed with mustard oil i.e. control (a), AO (1\%) shows tumor (b) on its lobe, while multiple nodules (c) were observed after dietary exposure of BY $(0.06 \%)$, for the duration of 180 days. V. B: Histological evaluation of liver section stained with $\mathrm{H} \& \mathrm{E}$, with $4 \mathrm{X}$ and $40 \mathrm{X}$ magnifications from (a) control (b) $1 \% \mathrm{AO}$ and (c) $0.06 \% \mathrm{BY}$ in female Swiss albino mice after 180 days of exposure. Control section shows normal histology; AO fed liver section showed hyperplasia of bile ductules; BY fed lived section showed hyperplasia of bile ductules and fluid filled space Total number of liver section from mice treated with control diet, AO and BY diet were three. 
Citation: Mishra V, Mishra M, Chaudhari BP, Khanna R, Das M (2014) Argemone Oil and Butter Yellow Induced Toxicity in Hepatic and Extra Hepatic Tissues. Bioenergetics 3: 111. doi:10.4172/2167-7662.1000111
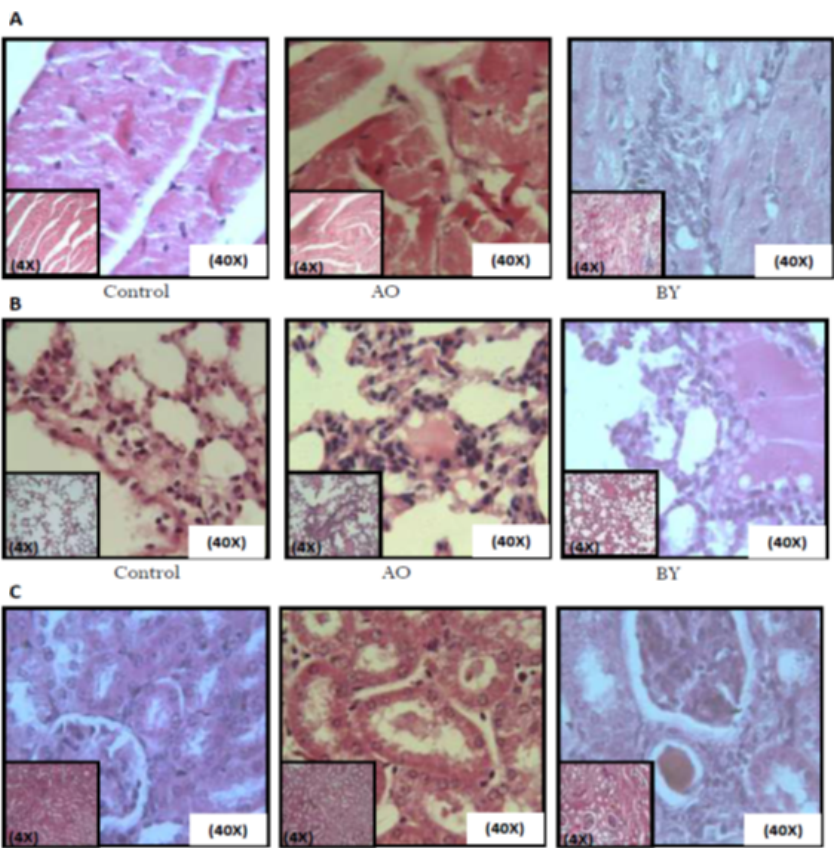

AO
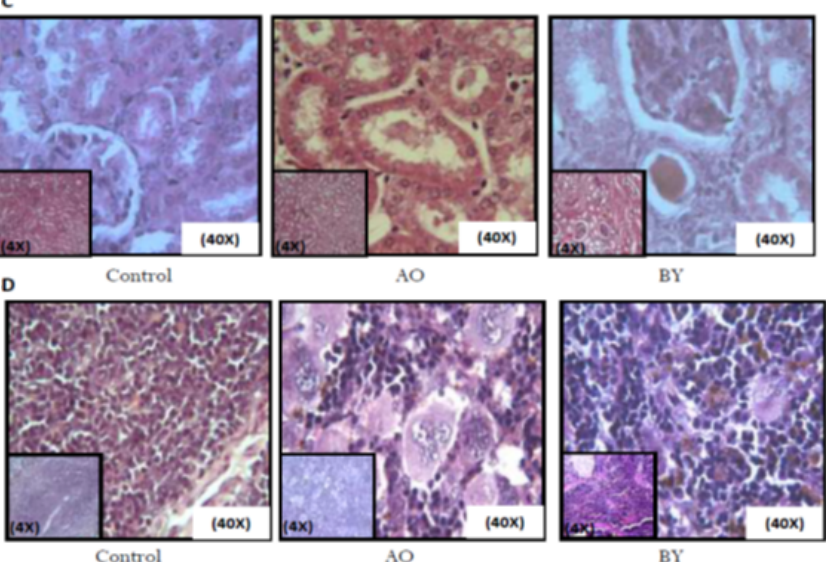

BY

Figure 3: Effect of dietary exposure of $A O$ and $B Y$ on histopathology of heart, lungs, kidney and spleen. (3A) Heart showing foci of inflammation, degeneration and necrosis in $\mathrm{AO}(1 \%)$ and myocardial necrosis and infiltration of inflammatory cells in BY $(0.06 \%)$ stained with $\mathrm{H} \& \mathrm{E}$, with $4 \mathrm{X}$ and $40 \mathrm{X}$ magnifications. (3B) Lung showing marked focus of edema with cellular infiltration of inflammatory cells in $\mathrm{AO}(1 \%)$ and $\mathrm{BY}(0.06 \%)$ stained with $\mathrm{H} \& \mathrm{E}$, with $4 X$ and $40 X$ magnifications. (3C) Kidney sections showing no prominent changes except the presence of protein cast within tubules in $A O(1 \%)$ and BY $(0.06 \%)$ stained with $\mathrm{H} \& E$, with $4 \mathrm{X}$ and $40 \mathrm{X}$ magnifications. (3D) Spleen showing profuse hyperplasia of bile ductules, lymphoid hypoplasia and prominent fibrous tissue septa in $\mathrm{AO}(1 \%)$ and prominent fibrous tissue and lymphoid hypoplasia along with few megakaryocytes in BY $(0.06 \%)$ stained with $\mathrm{H} \& \mathrm{E}$, with $4 \mathrm{X}$ and $40 \mathrm{X}$ magnifications.

all the major biomolecules including nucleic acids, proteins and lipids [41]. ROS have been implicated in a variety of disease states such as heart attack, strokes and arthritis [40]. Moreover, all the cells possess an antioxidant defense system for protection against free radicals [42]. If the antioxidant defense fails to scavenge or inhibit the production of ROS/oxidants, an imbalance occurs between pro and antioxidant, which is known to cause oxidative stress [40-42]. LPO is a free radical driven reaction, which causes tissue membrane damage by reaction of oxygen with polyunsaturated fatty acids (PUFAs) [40]. In the present study decrease in hepatic free $-\mathrm{SH}$ content with concomitant increase in lipid peroxidation in $\mathrm{AO}$ treated female mice suggests the membrane damaging potential of AO. It is well known that antioxidant defense enzymes (SOD, Catalase) scavenge or inhibit the production of ROS/ oxidants. Our results indicate that decrease in antioxidant enzymes (SOD, catalase) by AO and BY lead to the inability of defense system to scavenge ROS production in the body.
In conclusion, the study suggests female mice are more prone to $\mathrm{AO}$ and $\mathrm{BY}$ toxicity and adulteration of $\mathrm{AO}$ and $\mathrm{BY}$ may cause oxidative stress and decrease in phase I and II enzymes leading to accumulation of the parent compound(s) or their metabolites, which may result in the tumorigenic/toxic responses in hepatic and extra hepatic tissues.

\section{Conflict of Interest Statement}

The authors declare that there are no conflicts of interest.

\section{Acknowledgements}

We are grateful to the Director of our Centre for his keen interest in the study. One of us (V M) is thankful to Council of Scientific and Industrial Research (CSIR)/ University Grants Commission (UGC), New Delhi for the award of Junior Research Fellowship. Financial assistance of CSIR Network Project SIP-08 is gratefully acknowledged.

Financial support: CSIR Network Project SIP-08, University Grants Commission GAP-155.

\section{References}

1. Wharton BA (1980) Human nutrition. Science 209: 1011-1012.

2. Khan JS (2001) Blended mustard oil for health benefits: Health and dietary aspects of mustard oil, Mustard Research and Promotion Consortium, New Delhi, India.

3. Sarkar SL (1926) Katakar oil poisoning. Indian Med Gaz 61: 62-63.

4. Lal RB, Roy SC (1937) Investigation into epidemiology of Epidemic Dropsy. I Introductory notes and historical survey. Indian Med. Gaz 25: 163-167.

5. Chopra RN, Pasricha CL, Goyal RK, Lal S, Sen AK (1939) The experimental production of syndrome of epidemic dropsy in man. Indian Med. Gaz 74: 193198.

6. SARKAR SM (1948) Isolation from argemone oil of dihydrosanguinarine and sanguinarine; toxicity of sanguinarine. Nature 162: 265

7. Das M, Khanna SK (1998) Epidemic dropsy. Natl Med J India 11: 207-208

8. Chaudhuri R N (1959) Clinical and experimental research on feeding of argemone oil. Bull Cal School. Trop Med 7: 157-165.

9. Das M, Khanna SK (1997) Clinicoepidemiological, toxicological, and safety evaluation studies on argemone oil. Crit Rev Toxicol 27: 273-297.

10. Upreti KK, Das M, Kumar A, Singh GB, Khanna SK (1989) Biochemical toxicology of argemone oil. IV. Short-term oral feeding response in rats. Toxicology 58: 285-298.

11. Babu CK, Ansari KM, Mehrotra S, Patel S, Dikshit M, et al. (2010) Activation of inflammatory response and apoptosis of polymorphonuclear leukocytes in patients with argemone oil poisoning. ChemBiol Interact 183: 154-164.

12. CHANG JP, SPAIN JD, GRIFFIN AC (1958) Histochemical manifestations of early changes in rat liver during carcinogenesis induced by 3'-methyl-4dimethylaminoazobenzene. Cancer Res 18: 670-675.

13. Ashby J, Elliott BM, Lefevre PA, Styles J, Longstaff E (1983) Initiation/promotion versus complete carcinogenicity in the rodent liver. Environ Health Perspect 50 339-346.

14. Das M (2008) Food contamination and adulteration: Environmental Biochemistry, NatlSci Digital Lib, NatllnsttSci Communication \& Information Resource, New Delhi, India.

15. ZabezhinskiÄ MA, Pliss GB, Okulov VB, Petrov AS (1984) [Comparison of the effect of different carcinogens on the skin of rats]. EkspOnkol 6: 24-27.

16. International Agency for Research on Cancer (IARC) (1987) On the evaluation of carcinogenic risk of chemicals to man. Group 2B7: 440.

17. Ansari KM, Chauhan LK, Dhawan A, Khanna SK, Das M (2004) Unequivocal evidence of genotoxic potential of argemone oil in mice. Int J Cancer 112: 890895

18. Ansari KM, Dhawan A, Khanna SK, Das M (2005) In vivo DNA damaging potential of sanguinarine alkaloid, isolated from argemone oil, using alkaline Comet assay in mice. Food ChemToxicol 43: 147-153.

19. Upreti KK, Das M, Khanna SK (1991) Biochemical toxicology of argemone oil 
Citation: Mishra V, Mishra M, Chaudhari BP, Khanna R, Das M (2014) Argemone Oil and Butter Yellow Induced Toxicity in Hepatic and Extra Hepatic Tissues. Bioenergetics 3: 111. doi:10.4172/2167-7662.1000111

I. Effect on hepatic cytochrome P-450 and xenobiotic metabolizing enzymes. J Appl Toxicol 11: 203-209.

20. NELSON AA, WOODARD G (1953) Tumors of the urinary bladder, gall bladder, and liver in dogs fed o-aminoazotoluene or p-dimethylaminoazobenzene. J Natl Cancer Inst 13: 1497-1509.

21. Das M, Seth PK, Mukhtar H (1981) Characterization of microsomal aryl hydrocarbon hydroxylase of rat brain. J PharmacolExpTher 216: 156-161.

22. Ohkawa H, Ohishi N, Yagi K (1979) Assay for lipid peroxides in animal tissues by thiobarbituric acid reaction. Anal. Biochem 95: 351-358.

23. ELLMAN GL (1959) Tissue sulfhydryl groups. Arch BiochemBiophys 82: 70-77.

24. Misra HP, Fridovich I (1972) The role of superoxide anion in the autoxidation of epinephrine and a simple assay for superoxide dismutase. J BiolChem 247 : 3170-3175.

25. Sinha AK (1972) Colorimetric assay of catalase. Anal Biochem 47: 389-394.

26. Pohl RJ, Fouts JR (1980) A rapid method for assaying the metabolism of 7-ethoxyresorufin by microsomal subcellular fractions. Anal Biochem 107: 150155.

27. Lubet RA, Jones CR, Stockus DL, Fox SD, Nims RW (1991) Induction of cytochrome P450 and other drug metabolizing enzymes in rat liver following dietary exposure to Aroclor 1254. ToxicolAppIPharmacol 108: 355-365.

28. Das M, Rastogi S, Khanna SK (2004) Mechanism to study 1:1 stoichiometry of NADPH and alkoxyphenoxazones metabolism spectro- photometrically in subcellular biological preparations. Biochim. Biophys. Acta 1675: 1-11.

29. Lowry OH, Rosebrough NJ, Farr AL, Randall RJ (1951) Protein measurement with folin phenol reagent. J. Biol. Chem 193: 265-275.

30. Sebolt-Leopold JS, Dudley DT, Herrera R, Van Becelaere K, Wiland A, et al. (1999) Blockade of the MAP kinase pathway suppresses growth of colon tumors in vivo. Nat Med 5: 810-816.
31. Bogovski $P$ (1978) In: Pathology of Tumors in Laboratory Animals: Tumors of the Mouse. (2ndedn), International Agency for Cancer Research, IARC Scientific Publication, Lyon, France.

32. Snedecar GW, Cochran WG (1967) One way classification: analysis of variance. In: Statistical Methods. (6thedn), University Press, Ames, lowa, USA

33. Kiguchi K, Ruffino L, Kawamoto T, Franco E, Kurakata S, et al. (2007) Therapeutic effect of CS-706, a specific cyclooxygenase-2 inhibitor, on gallbladder carcinoma in BK5.ErbB-2 mice. Mol Cancer Ther 6: 1709-1717.

34. Ochs H, Düsterberg B, Günzel P, Schulte-Hermann R (1986) Effect of tumor promoting contraceptive steroids on growth and drug metabolizing enzymes in rat liver. Cancer Res 46: 1224-1232.

35. Schulte-Hermann R (1985) Tumor promotion in the liver. Arch. Toxicol 57: 147158

36. Peraino C, Fry RJ, Grube D (1978) Drug induced enhancement of hepatic tumorigenesis: Mechanisms of Tumor Promotion and Carcinogenesis, Raven Press, New York, USA.

37. Nims RW, Devor DE, Henneman JR, Lubet RA (1987) Induction of alkoxyresorufin O-dealkylases, epoxide hydrolase, and liver weight gain: correlation with liver tumor-promoting potential in a series of barbiturates. Carcinogenesis 8: 67-71.

38. Das M, Bickers DR, Santella RM, Mukhtar H (1985) Altered patterns of cutaneous xenobiotic metabolism in UVB-induced squamous cell carcinoma in SKH-1 hairless mice. J Invest Dermatol 84: 532-536.

39. Mishra V, Mishra M, Ansari KM, Chaudhari BP, Khanna R, et al. (2012) Edible oil adulterants, argemone oil and butter yellow, as aetiological factors for gall bladder cancer. Eur J Cancer 48: 2075-2085.

40. Kehrer JP (1993) Free radicals as mediators of tissue injury and disease. Crit Rev Toxicol 23: 21-48

41. Pryor WA (1982) Free radical biology: xenobiotics, cancer, and aging. Ann $N$ Y AcadSci 393: 1-22.

42. Yu BP (1994) Cellular defenses against damage from reactive oxygen species. Physiol Rev 74: 139-162. 